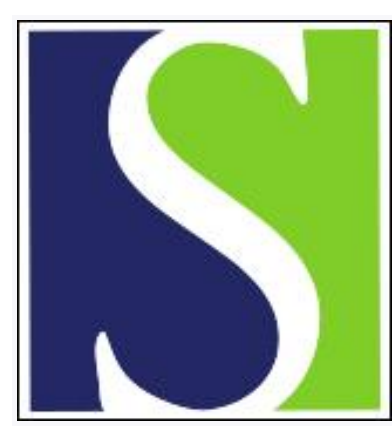

Scand J Work Environ Health 1997;23(1):24-30

https://doi.org/10.5271/sjweh.174

Issue date: Feb 1997

Cumulative lead exposure in relation to mortality and lung cancer morbidity in a cohort of primary smelter workers

by Lundström N-G, Nordberg G, Englyst V, Gerhardsson L, Hagmar L, Jin T, Rylander L, Wall S

Key terms: cohort study; copper-lead smelter; lung cancer

This article in PubMed: www.ncbi.nlm.nih.gov/pubmed/9098908

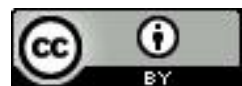




\title{
Cumulative lead exposure in relation to mortality and lung cancer morbidity in a cohort of primary smelter workers
}

\author{
by Nils-Göran Lundström, BSc, ${ }^{1}$ Gunnar Nordberg, MD, ${ }^{1}$ Vagn Englyst, MD, ${ }^{2}$ Lars Gerhardsson, MD, ${ }^{3}$ \\ Lars Hagmar, MD, ${ }^{3}$ Taiyi Jin, MD, Lars Rylander, BSc, ${ }^{3}$ Stig Wall, $P h D^{4}$
}

\begin{abstract}
Lundström N-G, Nordberg G, Englyst V, Gerhardsson L, Hagmar L, Jin T, Rylander L, Wall S. Cumulative lead exposure in relation to mortality and lung cancer morbidity in a cohort of primary smelter workers. Scand J Work Environ Health 1997;23(1):24-30.
\end{abstract}

Objectives The purpose of this study was to determine the mortality and cancer incidence of long-term lead smelter workers at a primary smelter.

Methods A cohort of 3979 workers employed for at least 1 year during 1928-1979 and a subcohort of 1992 workers employed in lead exposed departments (lead only workers) was formed. The expected mortality in 1955-1987 and cancer incidence in 1958-1987 were calculated relative to the county rates, specified for cause, gender, 5-year age groups, and calendar year. A cumulative blood-lead index was used for the doseresponse analyses.

Results The lung cancer incidence of the total cohort [standardized incidence ratio (SIR) $2.8,95 \%$ confidence interval (95\% CI) 2.1-3.8] and the group with the highest exposure (SIR 3.1, 95\% CI 2.0-4.6) was high. Similar risk estimates were observed with a latency of 15 years. The workers hired before 1950 had higher lung cancer risk estimates (SIR 3.6, 95\% CI 2.6-5.0) than the workers hired later (SIR 1.3, 95\% CI 0.6-2.6, no latency period). The risk estimates for lung cancer were further elevated in the subcohort of lead-only workers (SIR 5.1, 95\% CI 2.0-10.5 in the highest exposed subgroup; latency period of 15 years). No excesses of other malignancies were noted.

Conclusions The increased relative risks were probably mainly due to interactions between lead and other carcinogenic exposures, including arsenic. Further study is required concerning such possible interactions before a role in the induction of lung cancer can be ascribed to lead.

Key terms copper-lead smelter, cohort study, lung cancer.

Inorganic lead has been frequently used in human society for centuries. Well-known exposure sources include lead-based paint, industrial emissions, contaminated water, and traffic (1). Lead exposure in industry can take place in different industrial settings (eg, lead mining, smelting and refining plants, storage battery manufacturing, welding, steel cutting and printing) $(1,2)$. The highest observed air concentrations of inorganic lead have been reported for smelting and refining processes (3).

Several animal experiments have shown the carcinogenic potency of lead. Several lead compounds (eg, lead acetate and subacetate) have induced brain and kidney tumors in rats and mice (4-9) and lead phosphate kidney tumors in rats (9) after oral and parenteral adminis- tration. It, however, has not been clarified whether lead is a human carcinogen or not. In 1980 and 1987, the International Agency for Research on Cancer (IARC) classified lead and inorganic lead compounds as possible human carcinogens (group 2B).

Some epidemiologic studies on lead exposure and cancer have been reported in the literature. These studies were conducted in different occupational settings, and their major objective has been to examine the causal association between lead exposure and cancer. A recent meta-analysis (3) of available epidemiologic studies on lead-exposed workers has shown a significant excess risk of overall cancer, and of stomach, lung and bladder cancer. The risk ratios increased slightly for lung [rela-

1 Department of Occupational and Environmental Medicine, Umeå University, Umeå, Sweden.

2 Boliden Meditek, Skelleftehamn, Sweden.

3 Department of Occupational and Environmental Medicine, University Hospital, Lund, Sweden.

4 Department of Epidemiology and Public Health, Umeå University, Umeå, Sweden.

Reprint requests to: Dr Nils-Göran Lundström, Department of Occupational and Environmental Medicine, Umeå University, S-901 87 Umeå, Sweden. 
tive risk (RR) $1.4,95 \%$ confidence interval $(95 \% \mathrm{CI})$ 1.1-1.9] and stomach (RR 1.5, 95\% CI 1.2-1.8) cancer when the analysis was confined to heavily exposed workers. However, the analysis took no account of possible confounders, and little information was available on cumulative exposure to lead. A nonsignificantly increased relative risk for death from lung cancer (RR 1.6, 95\% CI 0.7-3.2) has previously been reported in a cohort study of lead smelter workers exposed long-term at a primary copper and lead smelter in northern Sweden (10). This study was based on 85 deaths (8 lung cancer cases) among 473 lead smelter workers followed from 1955 to 1981. In our investigation the study base was larger, the follow-up period was from 1955 to 1987, and mortality data was supplemented with cancer incidence data. An attempt has been made to compare the mortality and morbidity pattern for lead workers with the one for workers with mixed exposure.

\section{Subject and methods}

\section{Copper and lead smelter}

The main products of the smelter, which was started in 1928 in northern Sweden, are copper and lead. In addition, the company also recovers precious metals (eg, gold, silver, platinum), arsenic, nickel, selenium, zinc, and sulfur products from the ores.

Lead production started at the smelter in 1943. The production the first year was $90 \mathrm{t}$. In 1950, the production had reached $10000 \mathrm{t}$. During the $1950 \mathrm{~s}$ it gradually increased up to $40000 \mathrm{t}$ and was stable around $40000 \mathrm{t}$ during the $1960 \mathrm{~s}$. Thereafter, it increased to about $50000 t$ during the 1970 s. The highest lead production was reached in 1987 (63000 t). Then it gradually decreased to about 50 to $55000 \mathrm{t}$ in the early $1990 \mathrm{~s}$, and it has now stabilized around $40000 \mathrm{t}$ per year. The processes for obtaining lead have previously been described in detail (10).

\section{Cohort}

Information about worksites and employment periods at the smelter was obtained from the company. Record linkages were facilitated through the use of civic registration numbers, first introduced in Sweden in 1947. As information on civic registration was lacking for a substantial proportion of the workers, especially for those employed in 1928-1947, supplementary information was collected from the Swedish population register (SPAR) and from manual population registers kept by the parish authorities (11).

The cohort of primary smelter workers has been gradually extended over the years. It now comprises 7942 of 7957 male blue-collar workers, and male and female salaried employees, first employed for at least 3 months during the period 1928-1979. Fifteen subjects were lost to follow-up and could not be traced in the registers because of lack of personal identifiers. Regular blood lead sampling every 2 to 3 months has been performed at the smelter since 1950 . Our study cohort comprised the 3979 male workers of the total 7942 who have been monitored for their blood lead concentration $(\mathrm{B}-\mathrm{Pb})$ since 1950 . The records, however, contained no data on workers who had died before 1955 .

In this cohort of 3979 workers (table 1), 3523 were alive and 456 were deceased at the study end point, 31 December 1987, when vital status was determined. When workers who ever had been employed in departments where exposure to known carcinogens such as arsenic and nickel occur or at workplaces such as the roaster department and machine shop were excluded, a subgroup of 1992 workers remained, "lead-only workers". This group had mainly been employed in the lead-exposed departments.

\section{Blood-lead analyses}

The blood-lead level (B-Pb) was analyzed by emission spectrometry from 1950 to 1969 , and since 1967 atomic absorption has been used. The quality control program started already during the 1950s. Up to about 1970, a regular exchange of $\mathrm{B}-\mathrm{Pb}$ samples took place; laboratories in West Germany and the United Kingdom showed mostly satisfactory results $(12,13)$. In 1969, the quality control of $\mathrm{B}-\mathrm{Pb}$ had a precision of $9 \%$ and a systematic error of $-0.05 \mu \mathrm{mol} / 1$ (14). Thereafter, the research laboratory at the smelter has participated in a national quality control program coordinated by the National Board of Occupational Safety and Health in Stockholm, Sweden (15-17). All told, $81051 \mathrm{~B}-\mathrm{Pb}$ analyses have been

Table 1. Number of workers studied with respect to exposure category and latency period.

\begin{tabular}{|c|c|c|c|c|}
\hline & \multicolumn{2}{|c|}{ Mortality } & \multicolumn{2}{|c|}{ Morbidity } \\
\hline & No latency period & $\begin{array}{l}\text { Latency period of } \\
\text { at least } 15 \text { years }\end{array}$ & No latency period & $\begin{array}{l}\text { Latency period of } \\
\text { at least } 15 \text { years }\end{array}$ \\
\hline Total cohort & 3979 & 2357 & 3972 & 2353 \\
\hline Highest exposed subgroup & 1026 & 652 & 1022 & 650 \\
\hline Lead only workers & 1992 & 1005 & 1992 & 1005 \\
\hline Highest exposed subgroup & 326 & 163 & 326 & 163 \\
\hline
\end{tabular}


performed at the smelter from 1950 to 1987 . For these workers the cumulative $\mathrm{B}-\mathrm{Pb}$ dose has been calculated by summing the annual mean blood values for each worker $(\mu \mathrm{mol} / \mathrm{l})$ during their employment period.

For work periods before 1950, when the B-Pb monitoring program started, each worker was assumed to have had a $\mathrm{B}-\mathrm{Pb}$ level corresponding to his mean $\mathrm{B}-\mathrm{Pb}$ value during the period 1950 to 1952 . For work periods from 1950 on, the B-Pb samples were regularly obtained up to 4 to 6 times per year from the workers in the lead departments. For work periods in the other metal producing plants, the B-Pb sampling has been more sparse.

The lead exposure at the smelter has decreased continuously since the start of the B-Pb registration in 1950 . The annual mean (arithmetic) $\mathrm{B}-\mathrm{Pb}$ value of the lead smelter workers was $3.0 \mu \mathrm{mol} / \mathrm{l}$ in 1950 and approximately $1.6 \mu \mathrm{mol} / \mathrm{l}$ in 1987 . For the workers in the other metal-producing plants in the smelter the mean $\mathrm{B}-\mathrm{Pb}$ values have decreased from $2.7 \mu \mathrm{mol} / 1$ to $0.8 \mu \mathrm{mol} / \mathrm{l}$. The corresponding figures for other personnel at the smelter (eg, maintenance and transportation workers) were $2.6 \mu \mathrm{mol} / \mathrm{l}$ and $0.6 \mu \mathrm{mol} / \mathrm{l}$, respectively (18). Thus the lead exposure was not only confined to the lead departments.

\section{Information on causes of death and tumors}

Information about mortality in 1955-1987 was gathered from the Cause-of-Death Register at Statistics Sweden. The death certificates were coded according to the 8th revision of the International Classification of Diseases (ICD-8). Similarly, information on incident malignant tumors was based on record linkage with the national Swedish tumor register, established in 1958.

\section{Risk estimates}

The expected mortality for the period 1955-1987 was calculated with the use of mortality rates specific for calendar year, cause, gender, and 5-year age groups in the county population obtained from Statistics Sweden. Date of death, emigration, or a subject's 80th birthday were used as the individual end points, whichever occurred first. In a similar way, yearly cancer incidence rates were obtained for the period 1958-1987 from the national Swedish tumor registry. Date of death, a second tumor diagnosis, emigration, or a subject's 80th birthday were used as the individual end points, whichever occurred first. All the epidemiologic analyses were performed with the computer program EPILUND. The $95 \%$ confidence intervals ( $95 \% \mathrm{CI}$ ) for cause-specific standardized mortality ratios (SMR) and standardized cancer incidence ratios (SIR) were calculated according to the Poisson distribution or to the normal distribution when the expected values were greater than 15 .

\section{Results}

\section{Mortality}

In comparison with the county population, the mortality from malignant neoplasms was increased in the total cohort (SMR 1.2, 95\% CI 1.0-1.5), as well as in the highest exposed subgroup (cumulative $\mathrm{B}-\mathrm{Pb}$ index ( $\Sigma \mathrm{B}-\mathrm{Pb}) 10 \mu \mathrm{mol} / \mathrm{l}$, SMR $1.2,95 \%$ CI $0.9-1.5$ ) (table 2). The mortality from lung cancer was particularly increased in these groups (SMR 2.8, 95\% CI 2.0-3.8 and SMR 2.8, 95\% CI 1.8-4.5). No other excess risks were observed, and the overall mortality (SMR 0.9, 95\% CI $0.8-1.0$; SMR 0.8, 95\% CI 0.7-1.0), as well as mortality from ischemic heart disease, was slightly lower than for the county population. Only marginal changes were observed when a latency period of at least 10 or 15 years was applied. The mortality pattern of the leadonly subcohort was similar both with and without adjustment for a latency period of 10 or 15 years (data not shown). However, in the highest exposed subgroup of

Table 2. Mortality in the total cohort of 3979 lead-exposed workers (73 832 person-years) and in the highest exposed subgroup (1026 workers; 20173 person-years) in comparison with the county population, during the follow-up period of 1955-1987. (0= observed number of deaths, $\mathrm{E}=$ expected number of deaths, SMR $=$ standardized mortality ratio, $95 \% \mathrm{Cl}=95 \%$ confidence interval)

\begin{tabular}{|c|c|c|c|c|c|c|c|c|}
\hline \multirow[t]{2}{*}{ Cause of death ${ }^{\mathrm{a}}$} & \multicolumn{4}{|c|}{ Total cohort } & \multicolumn{4}{|c|}{ Highest exposed subgroup } \\
\hline & 0 & $E$ & SMR & $95 \% \mathrm{Cl}$ & 0 & E & SMR & $95 \% \mathrm{Cl}$ \\
\hline All causes & 456 & 504 & 0.9 & $0.8-1.0$ & 187 & 226 & 0.8 & $0.7-1.0$ \\
\hline Malignant neoplasms (140-209) & 126 & 102 & 1.2 & $1.0-1.5$ & 55 & 47.8 & 1.2 & $0.9-1.5$ \\
\hline $\begin{array}{l}\text { Lung cancer (1620-1621) } \\
\text { Cardiovascular diseases }(390-458)\end{array}$ & $\begin{array}{r}39 \\
234\end{array}$ & $\begin{array}{r}14 \\
268\end{array}$ & $\begin{array}{l}2.8 \\
0.9\end{array}$ & $\begin{array}{l}2.0-3.8 \\
0.8-1.0\end{array}$ & $\begin{array}{r}19 \\
106\end{array}$ & $\begin{array}{c}6.7 \\
128\end{array}$ & $\begin{array}{l}2.8 \\
0.8\end{array}$ & $\begin{array}{l}1.8-4.5 \\
0.7-1.0\end{array}$ \\
\hline $\begin{array}{l}\text { Ischemic heart diseases }(410-414) \\
\text { Cerebrovascular diseases }(430-438)\end{array}$ & $\begin{array}{r}152 \\
36\end{array}$ & $\begin{array}{l}186 \\
42.9\end{array}$ & $\begin{array}{l}0.8 \\
0.8\end{array}$ & $\begin{array}{l}0.7-1.0 \\
0.6-1.2\end{array}$ & $\begin{array}{l}65 \\
18\end{array}$ & $\begin{array}{l}89.4 \\
20.4\end{array}$ & $\begin{array}{l}0.7 \\
0.9\end{array}$ & $\begin{array}{l}0.6-0.9 \\
0.5-1.4\end{array}$ \\
\hline Respiratory diseases $(460-519)$ & 7 & 18.9 & 0.4 & $0.2-0.8$ & 3 & 9.1 & 0.3 & $0.1-1.0$ \\
\hline Digestive organs $(520-577)$ & 8 & 13.9 & 0.6 & $0.3-1.1$ & 2 & 6.1 & 0.3 & $0.04-1.2$ \\
\hline Accidents, poisoning and violence (800-999) & 52 & 62.1 & 0.8 & $0.6-1.1$ & 12 & 19.3 & 0.6 & $0.3-1.1$ \\
\hline
\end{tabular}

a Code of the International Classification of Diseases (8th revision) in parentheses. 
lead-only workers $(\Sigma \mathrm{B}-\mathrm{Pb}>10 \mu \mathrm{mol} / \mathrm{l})$, the SMR for all malignancies was somewhat increased to $1.5(95 \% \mathrm{CI}$ $0.8-2.4$ ), but the SMR for lung cancer was considerably higher (SMR 4.1, 95\% CI 1.5-9.0). Applying a latency period of 10 or 15 years raised this risk estimate only marginally (data not shown).

\section{Morbidity}

The morbidity data show that particularly the lung cancer incidence was increased in the total cohort (SIR 2.9, $95 \%$ CI 2.1-4.0). The highest exposed subgroup did not differ significantly from the rest of the cohort in this respect. A latency period of 10 or 15 years (table 3 ) did not affect these estimates either. Lead workers in the total cohort first employed before $1950(\mathrm{~N}=717)$, when the $\mathrm{B}-\mathrm{Pb}$ monitoring program started, contributed 18535 person-years of observation compared with the 51858 person-years of the workers first employed in 1950 and onwards $(\mathrm{N}=3255)$. The lung cancer incidence was considerably higher in the former subcohort (SIR 3.6, 95\% CI 2.6-5.0 versus SIR 1.3, 95\% CI 0.6-2.6).
The lead-exposed workers who had also been employed at the roasters or the arsenic or nickel plant or the machine shop had lung cancer incidence data of the same magnitude as that of the total cohort. In addition, when the analysis was restricted to the subcohort of lead-only workers, the lung cancer risks remained at a similar level both with and without adjustment for a latency period of at least 15 years (SIR 3.1, 95\% CI 1.7-5.2, latency period of 15 years) (table 4). However, lead-only workers first employed before $1950(\mathrm{~N}=228,6064$ personyears) had a considerably higher lung cancer risk (SIR $3.7,95 \%$ CI 1.8-6.6) than those first employed in 1950 and onwards (SIR 2.0, 95\% CI 0.6-4.6) $(\mathrm{N}=1764$, 26183 person-years). The risk estimates for lung cancer were increased in both the intermediate $(\Sigma \mathrm{B}-\mathrm{Pb} 2$ $10 \mu \mathrm{mol} / \mathrm{l}$ ) and the highest exposed subgroup ( $\mathrm{EB}-\mathrm{Pb}$ $>10 \mu \mathrm{mol} / \mathrm{l}$ ) of lead-only workers (SIR $4.5,95 \% \mathrm{CI}$ 1.8 -9.3, and SIR 5.1, 95\% CI 2.0-10.5, latency period of 15 years) (table 5). No lung cancer case was observed in the lowest lead exposure subgroup ( $\Sigma \mathrm{B}-\mathrm{Pb} 0$ $2 \mu \mathrm{mol} / 1)$. No excess of malignancies other than lung cancer was observed in the lead-only subcohort.

Table 3. Incidence of malignant tumors during the period 1958-1987 for 2353 lead-exposed workers ( 31754 person-years) with a 15year minimum latency period and in the highest exposed subgroup (650 workers, 11439 person-years) employing the same latency period. Comparisons have been made with the county population. $(0=$ observed number of cases, $E=$ expected number of cases, $\mathrm{SIR}=$ standardized incidence ratio, $95 \% \mathrm{Cl}=95 \%$ confidence interval)

\begin{tabular}{|c|c|c|c|c|c|c|c|c|}
\hline \multirow[t]{2}{*}{ Type of tumor } & \multicolumn{4}{|c|}{ Total cohort } & \multicolumn{4}{|c|}{ Highest exposed subgroup } \\
\hline & 0 & $\mathrm{E}$ & SIR & $95 \% \mathrm{Cl}$ & 0 & $\mathrm{E}$ & SIR & $95 \% \mathrm{Cl}$ \\
\hline Malignant neoplasms (140-209) & 172 & 164 & 1.1 & $0.9-1.2$ & 83 & 76.3 & 1.1 & $0.9-1.4$ \\
\hline Gastrointestinal $(150-154)$ & 31 & 40.1 & 0.8 & $0.5-1.1$ & 15 & 18.8 & 0.8 & $0.5-1.3$ \\
\hline Respiratory tract (160-162) & 48 & 16.9 & 2.8 & $2.1-3.8$ & 24 & 7.9 & 3.0 & $2.0-4.6$ \\
\hline Lung $(1620-1621)$ & 42 & 14.4 & 2.9 & $2.1-4.0$ & 23 & 6.7 & 3.4 & $2.2-5.2$ \\
\hline Kidney (180) & 7 & 7.7 & 0.9 & $0.4-1.9$ & 3 & 3.5 & 0.9 & $0.2-2.5$ \\
\hline Renal pelvis, ureter, bladder (181) & 12 & 10.9 & 1.1 & $0.6-1.9$ & 9 & 5.1 & 1.8 & $0.8-3.4$ \\
\hline Brain, nervous system (193) & 6 & 5.7 & 1.1 & $0.4-2.3$ & 4 & 2.5 & 1.6 & $0.4-4.2$ \\
\hline Lymphoma, myeloma (200-203) & 10 & 10.3 & 1.0 & $0.5-1.8$ & 3 & 4.6 & 0.7 & $0.1-1.9$ \\
\hline Leukemia (204-207) & 5 & 4.9 & 1.0 & $0.3-2.4$ & 1 & 2.2 & 0.5 & $0.01-2.5$ \\
\hline
\end{tabular}

a Code of the International Classifcation of Diseases (7th revision) in parentheses.

Table 4. Incidence of malignant tumors in 1958-1987 in a subcohort of 1005 workers (11 370 person-years) solely employed in leadexposed departments ("lead only workers") with a 15-year minimum latency period and in the highest exposed subgroup (163 workers, 2643 person-years) employing the same latency period. The comparisons have been made with the county population. ( $0=$ observed number of cases, $E=$ expected number of cases, $S I R=$ standardized incidence ratio, $95 \% \mathrm{CI}=95 \%$ confidence interval).

\begin{tabular}{|c|c|c|c|c|c|c|c|c|}
\hline \multirow[t]{2}{*}{ Type of tumor } & \multicolumn{4}{|c|}{ Total cohort } & \multicolumn{4}{|c|}{ Highest exposed subgroup } \\
\hline & 0 & $E$ & SIR & $95 \% \mathrm{Cl}$ & 0 & $\mathrm{E}$ & SIR & $95 \% \mathrm{Cl}$ \\
\hline Malignant neoplasms (140-209) & 44 & 51.2 & 0.9 & $0.6-1.2$ & 19 & 15.4 & 1.2 & $0.8-2.0$ \\
\hline Gastrointestinal $(150-154)$ & 6 & 12.3 & 0.5 & $0.2-1.1$ & 2 & 3.7 & 0.5 & $0.1-1.9$ \\
\hline Respiratory tract (160-162) & 16 & 5.3 & 3.0 & $1.8-5.0$ & 8 & 1.6 & 4.9 & $2.1-9.6$ \\
\hline Lung $(1620-1621)$ & 14 & 4.5 & 3.1 & $1.7-5.2$ & 7 & 1.4 & 5.1 & $2.0-10.5$ \\
\hline Kidney (180) & - & 2.5 & 0.0 & $0.0-1.5$ & - & 0.7 & 0.0 & $0.0-5.0$ \\
\hline Renal pelvis, ureter, bladder (181) & 3 & 3.4 & 0.9 & $0.2-2.6$ & 2 & 1.0 & 1.9 & $0.2-7.0$ \\
\hline Brain, nervous system (193) & 2 & 1.9 & 1,1 & $0.1-3.8$ & 1 & 0.5 & 1.9 & $0.1-10.5$ \\
\hline Lymphoma, myeloma (200-203) & 4 & 3.3 & 1.2 & $0.3-3.1$ & - & 0.9 & 0.0 & $0.0-4.0$ \\
\hline Leukemia $(204-207)$ & - & 1.6 & 0.0 & $0.0-2.3$ & - & 0.5 & 0.0 & $0.0-8.0$ \\
\hline
\end{tabular}

a Code of the International Classification of Diseases (7th revision) in parentheses 
Table 5. Observed $(0)$ and expected (E) lung cancer morbidity (International Classification of Diseases, 7 th revision, code $1620-1621$ ) in 1958-1987 for the workers solely employed in lead-exposed departments ("lead only workers") with respect to the cumulative blood-lead index in comparison with the county population (latency period of at least 15 years). (SIR = standardized incidence ratio, $95 \% \mathrm{Cl}=95 \%$ confidence interval)

\begin{tabular}{lcccc}
\hline $\begin{array}{l}\text { Cumulative blood lead } \\
\text { index }\end{array}$ & 0 & $E$ & SIR & $95 \% \mathrm{Cl}$ \\
\hline $0-2 \mu \mathrm{mol} / \mathrm{l}$ & - & 1.4 & 0.0 & $0.0-2.7$ \\
$2-10 \mu \mathrm{mol} / \mathrm{l}$ & 7 & 1.6 & 4.5 & $1.8-9.3$ \\
$>10 \mu \mathrm{mol} / \mathrm{l}$ & 7 & 1.4 & 5.1 & $2.0-10.5$ \\
\hline
\end{tabular}

\section{Discussion}

In consistency with a prior cohort study of mortality among lead-exposed workers at this smelter (10) our study showed an increased morbidity for lung cancer. The risk estimates for lung cancer incidence were somewhat higher in the medium and highest exposed groups of the subcohort of lead workers solely employed in lead-exposed departments than in the total cohort, ( $\Sigma \mathrm{B}-\mathrm{Pb} 2-10$ and $>10 \mu \mathrm{mol} / \mathrm{l}$, respectively). The risk estimates of these 2 exposure groups did not, however, differ significantly from each other. Applying a latency period of 10 or 15 years did not significantly affect the risk estimates. Workers first employed during the 1940s, when the airborne exposure levels at the smelter were probably higher than during later periods, had considerably higher lung cancer risks than workers first employed from 1950 on.

The mortality pattern of the county population differed from that of the population of Sweden as a whole. The county population had a lower total cancer mortality, especially for lung cancer, and a considerably higher mortality for stomach cancer compared with that of the national population. On the other hand, the county population had a somewhat higher total mortality and a higher mortality from cardiovascular diseases than the national population did.

The results from the mortality analysis show a general pattern similar to the one noted in the study from 1986 (10). Total mortality and mortality from circulatory diseases was lower than expected. As in the previous study, no obvious differences in lung cancer risk was present in relation to cumulative lead exposure in the nonselected material (total cohort). In contrast, when a group of lead-only workers was studied, a different picture emerged. The lung cancer risk estimates were particularly high in its medium and highest exposed subgroups.

The increased lung cancer morbidity observed in this study must be interpreted with caution since the number of highly exposed lung cancer cases was still fairly low, especially among the lead-only workers. Our risk esti- mates are considerably higher than those in a recently published meta-analysis (3), which reported a relative risk of $1.4(95 \%$ CI $1.1-1.9)$ when results from three studies of workers with heavy occupational exposure to lead were combined. Whether this finding is due to an interaction with other agents is not obvious at present. The SMR and SIR values for respiratory tract malignancies were not increased in a recently presented Swedish cohort study of lead-exposed secondary smelter workers (19) with low exposure to agents other than lead. An increased risk of lung cancer was associated with lead exposure in a recent Finnish case-referent study (20) in which only limited information about exposures other than lead was available.

Smoking is a well known risk factor for the development of lung cancer. However, data about smoking habits are lacking in this study. There are reports that smoking frequency may be higher in blue-collar workers as compared with the general population. However, recently published data (21) from a cohort study at this primary copper and lead smelter shows that the prevalence of daily smoking has gradually decreased during the last two decades among the workers. The smoking frequencies have, however, been comparable with national figures for similar social and occupational strata. In their cohort study, Sandström \& Wall (21) found that adjustment for smoking did not alter the lung cancer gradient between employment cohorts or between job categories. Moreover, it has been estimated (22) that confounding from smoking would increase the lung cancer risk up to $1.2(\mathrm{OR})$ in some occupations. According$1 \mathrm{y}$, it seems unlikely that confounding from smoking would explain any important part of the increased lung cancer incidence observed in our study.

The histological distribution has previously been reported for the lung cancers occurring in workers at this primary smelter (23). No pronounced differences were found among smokers when the smelter workers and referents were compared. An increased proportion of adenocarcinomas was observed among the smelters, but these findings were difficult to interpret. The cases among smelter workers who had never smoked showed a histological distribution similar to that of smokers. This finding indicates that the exposure to carcinogenic agents at the smelter would influence the risk of different histological types of lung cancer the same way as smoking does.

One problem with studies of primary smelter workers is the concomitant exposure to other metals (2426); this problem also exists for lead-exposed workers (27). Increased lung cancer mortality and morbidity has been connected with exposure to arsenic, which has been reported in several epidemiologic studies $(28-38)$. A multiplicative effect for concomitant exposure to arsenic and smoking has been shown by Pershagen et al (31). 
Previous studies of tissue concentrations of trace elements in deceased workers at this smelter (39) have indicated a multifactorial genesis for lung cancer. Smoking has probably had a major impact on the lung cancer group. However, workers who died from lung cancer had the highest concentrations of antimony, arsenic, cadmium, lanthanum, and lead and the lowest selenium levels in lung tissue compared with workers who died of other diseases $(39,40)$. The workers have also been exposed to irritating gases such as sulfur dioxide and to polyaromatic hydrocarbons (eg, benzo[a]pyrene).

Dust sampling had occasionally took place at fixed sampling stations since the early 1940s. Airborne lead levels could have exceeded $1 \mathrm{mg} / \mathrm{m}^{3}$ at the lead plant during the 1940s. Arsenic concentrations ranged from $0.35-1.5 \mathrm{mg} / \mathrm{m}^{3}$ at the roasters during the late $1940 \mathrm{~s}$ and decreased to $0.1-0.5 \mathrm{mg} / \mathrm{m}^{3}$ during the $1950 \mathrm{~s}$. The corresponding sulfur dioxide levels ranged from 70 to $560 \mathrm{mg} / \mathrm{m}^{3}$ during the $1940 \mathrm{~s}$ and decreased to 5 $10 \mathrm{mg} / \mathrm{m}^{3}$ during the $1960 \mathrm{~s}$. The exposure to asbestos fibers and silica dust has been low at the smelter.

The dominant exposure to lead is in the form of slowly soluble oxides and sulfides, which can be expected to have a long biological half-time in the lungs. Interactions between lead and other metals such as arsenic, smoking, and other air pollutants may be the basis for the increased lung cancer risks observed at the smelter.

Cohort studies in lead smelter and battery workers are often hampered by limited information about cumulative lead exposure and concomitant exposure to other agents, as well as by limited data about smoking and dietary habits. However, in our study, the $\mathrm{B}-\mathrm{Pb}$ material collected is unique, as regular $\mathrm{B}-\mathrm{Pb}$ sampling has taken place at the smelter since 1950 . For some workers, more than $300 \mathrm{~B}-\mathrm{Pb}$ samples have been obtained during their employment period. Furthermore, no lung cancer screening program has been undertaken at the smelter. As far as we know, the registration of lung cancer cases among smelter workers has been similar to that of the county population. Moreover, data from the national Swedish Cancer Register have a high validity. As shown by Mattsson (41), about $96 \%$ of all newly diagnosed lung cancer cases are reported to the register. Thus the cancer incidence results presented in this study probably have a higher validity than the mortality data.

The increased relative risk for stomach cancer observed in a recent meta-analysis of 4 studies of workers with heavy occupational exposure to lead (3) and in a previous cohort study of secondary lead-smelter workers in southern Sweden (19) could not be confirmed in this study since there was no evidence for any excess of gastrointestinal malignancies. As is evident from tables 2 to 4 , the cancer incidence was not increased at any other site, which, however, may have been due to a lack of statistical power.

In summary, the mortality and morbidity from lung cancer was increased in this study, particularly in highly exposed lead workers solely employed in lead-exposed departments. The workers first employed before 1950 had considerably higher risk estimates than those first employed during later periods. The elevated risk estimates cannot solely be explained by confounding from smoking. The increased relative risks are probably mainly caused by synergism between lead and other carcinogenic exposures, including arsenic. Further studies are required concerning such possible interactions before a role can be ascribed to lead in the induction of lung cancer.

\section{Acknowledgments}

This work was supported by grants from the Swedish Work Environment Fund and the Medical Faculty of the University of Umeå and the Medical Faculty of the University of Lund.

\section{References}

1. Skerfving S. Inorganic lead: Nordic expert group for criteria documents. Stockholm: Arbetarskyddsverket, 1993:125-238.

2. World Health Organization (WHO). Lead. Geneva: WHO, 1977:160 pp. Environmental health criteria, 3.

3. Fu H, Boffetta P. Cancer and occupational exposure to inorganic lead compounds: a meta-analysis of published data. Occup Environ Med 1995;52:73-81.

4. Zollinger HU. Durch chronische Bleivergiftung erzeugte Nierenadenome und -carcinome bei Ratten und ihre Beziehungen zu den entsprechenden Neubildungen des Menschen. Virchows Arch 1953;323:694 -710.

5. Tanner DC, Lipsky MM. Effect of lead acetate on N-(4'fluoro-4-biphenyl)acetamide-induced renal carcinogenesis in the rat. Carcinogenesis 1984;5:1109-13.

6. Kasprzak KS, Hoover KL, Poirier LA. Effects of dietary calcium acetate on lead subacetate carcinogenicity in kidneys of male Sprague-Dawley rats. Carcinogenesis 1985;6:279-82.

7. Koller LD, Kerkvliet NI, Exon JH. Neoplasia induced in male rats fed lead acetate, ethyl urea, and sodium nitrite. Toxicol Pathol 1985;13:50-7.

8. Nogueira, E. Rat renal carcinogenesis after chronic simultaneous exposure to lead acetate and $\mathrm{N}$-nitrosodiethylamine. Virchows Arch [B] 1987;53:365-74.

9. International Agency for Research on Cancer (IARC). Overall evaluations of carcinogenicity: an updating of IARC monographs, volumes 1 to 42 . Lyon: IARC 1987:230-2. IARC monographs on the evaluation of carcinogenic risks to humans, suppl 7. (ISBN 9283214110 )

10. Gerhardsson L, Lundström N-G, Nordberg G, Wall S. Mortality and lead exposure: a retrospective cohort study of Swedish smelter workers. Br J Ind Med 1986;43:707-12. 
11. Sandström A. Epidemiology at a smeltery: changing patterns concerning lung cancer occurrence, work environment, smoking and risk perceptions over six decades [dissertation]. Umeå (Sweden): Department of Epidemiology and Health Care Research, University of Umeå, 1992.

12. Hoschek R. Parallelbestimmungen des Bleispiegels in verschiedenen Instituten. Archiv Gewerbepathol Gewerbehyg $1963 ; 20: 195-216$.

13. Holmqvist I. Monitoring and control of lead health risks at a Swedish smelter. London: Lead Development Association, 1976.

14. Gerhardsson L. Trace elements in tissues of deceased smelter workers - relationship to mortality. Umeå (Sweden): University of Umeå, 1986:1-184. Umeå University medical dissertations, new series 165 .

15. Vahter M, editor. Assessment of human exposure to lead and cadmium through biological monitoring (Prepared for UNEP and WHO). Stockholm: National Swedish Institute of Environmental Medicine and Karolinska Institute, Department of Environmental Hygiene, 1982:1-136.

16. Friberg L, Vather M. Assessment of exposure to lead and cadmium through biological monitoring: results of a UNEP/ WHO global study. Environ Res 1983;30:95-128.

17. Wrangskog K. Interlaboratoriekontroll avseende bestämning av bly i blod. Stockholm: Arbetarskyddsverket, 1984;15:1 25.

18. Gerhardsson L, Attewell R, Chettle DR, Englyst V, Lundström N-G, Nordberg GF, et al. In vivo measurements of lead in bone in long-term exposed lead smelter workers. Arch Environ Health 1993;48:147-56.

19. Gerhardsson L, Hagmar L, Rylander L, Skerfving S. Mortality and cancer incidence among secondary lead smelter workers. Occup Environ Med 1995;52:667-72.

20. Anttila A, Heikkilä P, Pukkala E, Nykyri E, Kauppinen T, Hernberg $S$, et al. Excess lung cancer among workers exposed to lead. Scand J Work Environ Health 1995;21:460-9.

21. Sandström A, Wall S. Lung cancer, smoking and smelter work in an occupational cohort. Int J Epidemiol 1995;24:1071—7.

22. Siemiatycki J, Wacholder S, Dewar R, Cardis E, Greenwood $\mathrm{C}$, Richardson L. Degree of confounding bias related to smoking, ethnic group, and socioeconomic status in estimates of the association between occupation and cancer. J Occup Med 1988:30:617-25.

23. Pershagen G, Bergman F, Klominek J, Damber L, Wall S. Histological types of lung cancer among smelter workers exposed to arsenic. Br J Ind Med 1987;44:454-8.

24. Cooper WC, Wong O, Kheifets L. Mortality among employees of lead battery plants and lead-producing plants, 19471980. Scand J Work Environ Health 1985;11:331 45.

25. Selevan SG, Landrigan PJ, Stern FB, Jones JH. Mortality of lead smelter workers. Am J Epidemiol 1985;122:673-83.

26. Ades AE, Kazantzis G. Lung cancer in a non-ferrous smelter: the role of cadmium. Br J Ind Med 1988;45:435-42.

27. Gerhardsson L, Brune D, Nordberg GF, Wester PO. Multielemental assay of tissues of deceased smelter workers and controls. Sci Total Environ 1988;74:97-110.

28. Lee AM, Fraumeni JF. Arsenic and respiratory cancer in man: an occupational study. JNCI 1969;42:1045-52.

29. Axelsson O, Dahlgren E, Jansson C-D, Rehnlund SO. Arsenic exposure and mortality: a case-referent study from a Swedish copper smelter. Br J Ind Med 1978;35:8-15.

30. Pinto SS, Henderson V, Enterline PE. Mortality experience of arsenic-exposed workers. Arch Environ Health 1978;33:32531.

31. Pershagen G, Wall S, Taube A, Linnman L. On the interaction between occupational arsenic exposure and smoking and its relationship to lung cancer. Scand $J$ Work Environ Health 1981;7:302-9

32. Enterline PE, March GM. Cancer among workers exposed to arsenic and other substances in a copper smelter. Am J Epidemiol 1982;116:895-911.

33. Welch K, Higgins I, Oh M, Burchfiel C. Arsenic exposure, smoking and respiratory cancer in copper smelter workers. Arch Environ Health 1982;37:325-35.

34. Lee-Feldstein A. Arsenic and respiratory cancer in humans: follow-up of copper smelter employees in Montana. JNCI 1983;70:601-10.

35. Higgins ITT, Welch KB, Oh MS, Kryston KL, Burchfield CM, Wilkinson NM. Arsenic exposure and respiratory cancer in a cohort of 8044 Anaconda smelter workers: a 43-year follow-up study (final report). Washington (DC): Chemical Manufacturers' Association, 1985.

36. Lee-Feldstein A. Cumulative exposure to arsenic and its relationship to respiratory cancer among copper smelter employees. J Occup Med 1986;28:296-302.

37. Enterline PE, Henderson VL, Marsh GM. Exposure to arsenic and respiratory cancer: a reanalysis. Am J Epidemiol 1987; 125:929-38.

38. Enterline PE, Day R, Marsh GM. Cancers related to exposure to arsenic at a copper smelter. Occup Environ Med 1995;52: $28-32$.

39. Gerhardsson L, Brune D, Nordberg GF, Wester PO. Protective effect of selenium on lung cancer in smelter workers. Br J Ind Med 1985;42:617-26.

40. Gerhardsson L, Brune D, Nordberg GF, Wester PO. Distribution of cadmium, lead, and zinc in lung, liver and kidney in long-term exposed smelter workers. Sci Total Environ 1986; $50: 65-85$.

41. Mattsson B. Cancer registration in Sweden; studies on completeness and validity of incidence and mortality register [dissertation]. Stockholm: Karolinska Institute, 1984.

Received for publication: 5 May 1996 